\title{
Fertilisation with Compost: Effects on Soil Phosphorus Sorption and on Phosphorus Availability in Acid Soils
}

\author{
Carmo Horta \\ CERNAS/IPCB, Research Centre for Natural Resources, Environment and Society/Polytechnic Institute of Castelo Branco, Castelo \\ Branco, Portugal \\ Email: carmoh@ipcb.pt
}

How to cite this paper: Horta, C. (2019) Fertilisation with Compost: Effects on Soil Phosphorus Sorption and on Phosphorus Availability in Acid Soils. Open Journal of Soil Science, 9, 255-268. https://doi.org/10.4236/ojss.2019.912016

Received: November 29, 2019

Accepted: December 28, 2019

Published: December 31, 2019

Copyright $\odot 2019$ by author(s) and Scientific Research Publishing Inc. This work is licensed under the Creative Commons Attribution International License (CC BY 4.0).

http://creativecommons.org/licenses/by/4.0/ cC) (†) Open Access

\begin{abstract}
Phosphate mineral fertilisers are manufactured from non-renewable resources. Soil fertilisation with composts is considered a good source of reuse nutrients such as phosphorus $(\mathrm{P})$. The aim of this work was to evaluate the effect of compost fertilisation on soil $\mathrm{P}$ sorption and consequently on $\mathrm{P}$ availability. It was done an incubation experiment followed by a sorption experiment in a low-P acid soil fertilised with compost (CP) or single superphosphate (SSP). The $\mathrm{P}$ application rates were: $0,6.5,13,26$ and 52 (kg.P.ha $\left.{ }^{-1}\right)$. In CP treatments, the rates 26 and $52 \mathrm{~kg} \cdot \mathrm{P} \cdot \mathrm{ha}^{-1}$ were achieved by adding SSP to CP since it was not allowed to incorporate into soil more than $170 \mathrm{~kg} \cdot \mathrm{N} \cdot \mathrm{ha}^{-1}$ from organic amendments. Although SSP has a higher proportion of easily available $\mathrm{P}$ than $\mathrm{CP}$ ( $86 \%$ vs $50 \%)$, the results showed that after 140 days of soil incubation, the available $\mathrm{P}$ was higher in $\mathrm{CP}$ treatments compared with SSP at the same rate of $\mathrm{P}$ application. The sorption experiment showed that after incubation of the fertilised soils, the $\mathrm{P}$ sorption maximum had lower values in treatments with CP in combination with SSP compared with only SSP fertilisation and the bonding energy had a deeper decrease in the same treatments. Also, the Standard Phosphate Requirement decreased in the CP in combination with SSP treatments. The reduction of soil P sorption capacity after compost addition to soil highlights the need of reducing $P$ fertilisation rates to achieve similar levels of available $\mathrm{P}$ compared with only SSP fertilisation.
\end{abstract}

\section{Keywords}

Ammonium Lactate Method, Olsen Method, Sustainability of P Fertilization, Standard Phosphate Requirement 


\section{Introduction}

The phosphorus $(\mathrm{P})$ availability depends on the $\mathrm{P}$ sorption/desorption processes between the solid and the liquid phases of the soil. Phosphate sorption occurs onto sites of variable-charged soil constituents. The main phosphate-sorbing surfaces in soils are those of $\mathrm{Al}$ and $\mathrm{Fe}$ oxides, hydroxides, and oxyhydroxides, which are collectively referred to as oxides [1] [2] [3] [4], organic complexes of $\mathrm{Al}$ and $\mathrm{Fe}$ [5], edges of silicate clays, and calcite [6]. In acid soils of the temperate region [7], it showed that the main surfaces that sorbed $\mathrm{P}$ are the poor crystalline $\mathrm{Al}$ and $\mathrm{Fe}$ hydroxides and organo-complexes of $\mathrm{Al}$ and $\mathrm{Fe}$. In turn, the desorbed $\mathrm{P}$ comes mainly from those soil constituents, being the degree of $\mathrm{P}$ saturation well correlated with the desorbed $\mathrm{P}$ indicating that the larger the amount of $\mathrm{P}$ sorbed, the less firmly it was held to soil solid phase. In order to improve the sustainability of soil P fertilisation and the objectives of the circular economy, the use of $\mathrm{P}$ mineral fertilisers must decrease and the use of other $\mathrm{P}$ sources has to increase. Some of these sources of $\mathrm{P}$ include the use of composts which contains organic matter $(\mathrm{OM})$ in addition to $P$. However, within the factors that affect soil P sorption, capacity is the organic matter of the soil. The role of the organic matter addition to soils on $\mathrm{P}$ sorption/desorption and consequently on soil $\mathrm{P}$ availability is addressed in several works, but sometimes with contradictory conclusions as summarized by the works of Gérard, 2016 [8] and Guppy et al., 2005 [9]. Some of those works [8] and [9] referred that the mineralisation of the OM added to soil releases several organic carbon compounds which has the potential to increase $\mathrm{P}$ concentration in the soil solution and thus increase $\mathrm{P}$ availability. The main processes to explain this conclusion include: 1) Competitive sorption between humic and fluvic acids [10] [11] [12] or low molecular weight aliphatic acids (LOA) and P for soil sorption sites resulting in increased $\mathrm{P}$ concentration in the soil solution [13] [14] [15]; 2) Metal complexation with OM compounds (LOA) or dissolution reactions affecting mainly $\mathrm{Fe}$ an $\mathrm{Al}$ oxides decreasing P sorption sites [14] [16] and 3) Sorption of OM compounds that could increase the negative charge on the soil surface, or decrease the point of zero charge (PCZ) increasing the resistance to P sorption. Unlike these effects, OM added to soil could increase the formation of metal bridges leading to increased $\mathrm{P}$ sorption sites [17] or in turn the P content of the added OM could also be a source of available P to soil solution [18] [19]. To assess P phytoavailability, some soil tests P (STP), like the Olsen (Olsen-P, [20]) and the Ammonium Lactate (AL-P, [21]) are commonly used. The Olsen method is used worldwide mainly in neutral and alkaline soils, but it could also be used in moderately acid soils as demonstrated by [22]. The Egnér et al. method is a routine soil test in some countries in Europe like in Belgium (Flandres), Norway, Portugal and Sweden [23]. These methods should provide accurate agronomic meaning in order to achieve a sustainable $\mathrm{P}$ fertilisation. Olsen method extracts $\mathrm{P}$ linked mainly from clay-humic complexes whereas Egnér method extracts $\mathrm{P}$ mainly adsorbed or precipitated on $\mathrm{Fe}$ and $\mathrm{Al}$ oxyhydroxides [23]. However, the proper- 
ties of composts, namely the organic matter content together with the $\mathrm{P}$-chemical forms in the fertilisers, could influence soil $\mathrm{P}$ sorption surfaces after fertilisation and consequently change the amount of P extracted by the STP. Using the same rate of $\mathrm{P}$ fertilisation applied through organic or mineral fertilisers (e.g. compost (CP) or single superphosphate (SSP)), we hypothesised that the $\mathrm{OM}$ of the $\mathrm{CP}$ will influence the $\mathrm{P}$ sorption processes enhancing the amount of $\mathrm{P}$ released to the soil solution compared to the mineral fertiliser. So, the main objective of this work was to evaluate the effects of compost fertilisation on $\mathrm{P}$ sorption and consequently on $\mathrm{P}$ availability. $\mathrm{P}$ availability was assessed by two soil tests commonly used in Europe, the Olsen and AL-P methods after application of compost or single superphosphate to a low-P acid soil.

\section{Material and Methods}

In order to assess changes in soil $\mathrm{P}$ availability caused by $\mathrm{P}$ fertilisation using $\mathrm{CP}$ or SSP fertilisers it was done an incubation experiment followed by a sorption experiment. This work was conducted in the Polytechnic Institute of Castelo Branco, Portugal, in 2017-2018.

\subsection{Incubation Experiment}

The soil used in the incubation experiment was a dystric Regosol [24], derived from granitic rock. A composite soil sample, taken from the layer $0-0.20 \mathrm{~m}$, was air dried and sieved in a $<2$ mm-mesh sieve. The soil used was acidic $\left(\mathrm{pH}_{\left(\mathrm{H}_{2} \mathrm{O}\right)}\right.$ $=5.1$ ), of sandy loam texture ( $8 \%$ clay, $18 \%$ silt and $74 \%$ sand), low cation exchange capacity $\left(8.3 \mathrm{cmol}_{(+)} \cdot \mathrm{kg}^{-1}\right)$, medium level of organic matter $\left(20 \mathrm{~g} \cdot \mathrm{kg}^{-1}\right)$, low level of available P (Olsen P of $10 \mathrm{mg} \cdot \mathrm{kg}^{-1}$ and AL-P of $21 \mathrm{mg} \cdot \mathrm{kg}^{-1}$ ) and low degree of $\mathrm{P}$ saturation $\left(16 \%, \quad \boldsymbol{D P S}=\frac{\text { Pox }}{0.5(\text { Feox }+ \text { Alox })}\right.$.

In the degree of $\mathrm{P}$ saturation equation (DPS) Pox, Feox and Alox are the amount of acid oxalate-extractable $\mathrm{P}, \mathrm{Fe}$ and $\mathrm{Al}$ expressed in mmol. $\mathrm{kg}^{-1}$. The incubation experiment was performed during 140 days. The fertilisers used were a commercial compost obtained through aerobic composting of sewage sludge mixed with sawdust during 5 months (CP) and the single superphosphate (SSP). The experimental design was a completely randomized design with two fertilizers (compost and single superphosphate), four $\mathrm{P}$ application rates and four replications of each treatment, and a control without fertilisation generating a total of 36 incubation boxes. The P application rates $\left(\mathrm{kg} \cdot \mathrm{P} \cdot \mathrm{ha}^{-1}\right)$ were: 6.5, 13, 26 and 52. The SSP treatments were as follows: SSP6.5, SSP13, SSP26 and SSP52. Concerning CP treatments and according to the Portuguese guidelines the amount of compost used was constrained by the level of $\mathrm{N}$ for a sustainable fertilisation with a maximum application rate of $170 \mathrm{~kg} \cdot \mathrm{N} \cdot \mathrm{ha}^{-1} \cdot \mathrm{year}^{-1}$ from organic amendments [25]. Therefore, P application rates of 26 and $52 \mathrm{~kg} \cdot \mathrm{ha}^{-1}$ of the CP treatments were achieved through the addition of SSP to the compost (CP + SSP): the rate of $26 \mathrm{~kg} \cdot \mathrm{P} \cdot \mathrm{ha} \mathrm{a}^{-1}$ was set by adding $19.5 \mathrm{~kg} \cdot \mathrm{P} \cdot \mathrm{ha} \mathrm{a}^{-1}$ in the form of SSP and use a 
compost amount corresponding to the half-amount of maximum $\mathrm{N}$ input (CP6.5 + SSP19.5), and the $52 \mathrm{~kg} \cdot \mathrm{P} \cdot \mathrm{ha}^{-1}$ rate by adding $39 \mathrm{~kg} \cdot \mathrm{P} \cdot \mathrm{ha}^{-1}$ in the form of SSP and use a compost amount corresponding to the maximum $\mathrm{N}$ input (CP13 + SSP39). The treatment CP6.5 was achieve with a compost amount corresponding to the half-amount of maximum $\mathrm{N}$ input and the $\mathrm{CP} 13$ with a compost amount corresponding to the maximum $\mathrm{N}$ input. The compost and the SSP were finely grounded to $0.5 \mathrm{~mm}$ and sieved before applying to the soil, and maintained in the dark at $25^{\circ} \mathrm{C}$ and at $70 \%$ of field capacity. After 15 and 140 days of incubation (S15 and S140), a composite soil sample was taken of each treatment and repetition and analysed for Olsen-P and AL-P. These sampling dates were chosen to simulate the level of soil available $\mathrm{P}$ at sowing (usually after 15 days from the date of the fertilisation) and at the end of a crop cycle $(\approx 140$ days).

\subsection{P Sorption Experiment}

After the incubation period the $\mathrm{P}$ sorption capacity of the soil of all the treatments was evaluated.

The method of Fox \& Kamprath, 1970 [26] was used to construct the P sorption (i.e. Q/I) curve; however, we used $0.002 \mathrm{M} \mathrm{CaCl}_{2}$ as the supporting electrolyte to better match the ionic strength of the soil solution. The $\mathrm{P}$ rates ( $\mu \mathrm{g} \cdot \mathrm{P} \cdot \mathrm{g}^{-1} \cdot$ soil) applied to the soil were: $0,10,25,50,70,100$ and 150 . Sorption data (seven points) were fitted to the following Freundlich curve

$$
Q s=A C^{b}
$$

where $A$ and $b$ are constants typical of each soil, namely $b$ is a constant that relates to the affinity of the sorbent for $P . C\left(\mathrm{mmol} \cdot \mathrm{L}^{-1}\right.$ or $\left.\mathrm{mg} \cdot \mathrm{L}^{-1}\right)$ is the concentration of $P$ in the soil solution, and $Q s\left(\mathrm{mmol} \cdot \mathrm{kg}^{-1}\right.$ or $\left.\mathrm{mg} \cdot \mathrm{kg}^{-1}\right)$ the total amount of $P$ sorbed by the soil.

Sorption data were fitted also to the Langmuir isotherm:

$$
Q s=\frac{(K Q \max C)}{(1+K C)}
$$

where $Q_{\max }\left(\mathrm{mmol} \cdot \mathrm{kg}^{-1}\right.$ or $\left.\mathrm{mg} \cdot \mathrm{kg}^{-1}\right)$ is the $P$ sorption maxima, and $K\left(\mathrm{~L} \cdot \mathrm{mg}^{-1}\right)$ is a constant that relates to the bonding energy of phosphate to the soil solid phase.

\subsection{Methods Used in the Chemical Characterisation of the Fertilisers and of the Soil}

The compost was assessed for its moisture content through the gravimetric method; acidity $(\mathrm{pH})$, with a glass electrode in a suspension of compost and water $(1: 5, \mathrm{wt} / \mathrm{vol})$; electrical conductivity, in a suspension of compost and water $(1: 10$, $\mathrm{wt} / \mathrm{vol}$ ); organic matter, through the loss of weight after drying at $550^{\circ} \mathrm{C}$ for $16 \mathrm{~h}$; and total $\mathrm{N}$, by the Kjeldahl procedure $\left(\mathrm{N}_{\mathrm{k}}\right)$.

The compost was digested with aqua regia solution $\left(\mathrm{HNO}_{3}+\mathrm{HCl}\right)$ according to the CEN EN 13346:2000 [27] and quantified for its amount of P, by molecular 
absorption spectrophotometry; total cations ( $\mathrm{Fe}, \mathrm{Mn}, \mathrm{Cu}, \mathrm{Pb}, \mathrm{Cd}, \mathrm{Ni}$ and $\mathrm{Cr}$ ), by atomic absorption spectrophotometry. Total $\mathrm{K}, \mathrm{Ca}, \mathrm{Mg}$ and $\mathrm{Na}$, were extracted from the hydrochloric acid solution of the ashes. $\mathrm{K}$ and $\mathrm{Na}$ were quantified by flame emission spectrophotometry and $\mathrm{Ca}$ and $\mathrm{Mg}$ by atomic absorption spectrophotometry. The class of stability/maturity of the compost was evaluated by the Dewar self-heating method ([28]).

$\mathrm{P}$ forms in the CP and in the SSP were evaluated by the sequential fractionation scheme of Traoré et al., 1999 [29], using a compost to solution ratio of 1:200 (wt/vol). The first extraction was performed with $\mathrm{H}_{2} \mathrm{O}\left(\mathrm{H}_{2} \mathrm{O}-\mathrm{P}\right)$, the second with $0.5 \mathrm{M} \mathrm{NaHCO}_{3}\left(\mathrm{pH} 8.5 ; \mathrm{NaHCO}_{3}-\mathrm{P}\right)$, the third with $0.1 \mathrm{M} \mathrm{NaOH}(\mathrm{NaOH}-\mathrm{P})$ and fourth with $1 \mathrm{M} \mathrm{HCl}(\mathrm{HCl}-\mathrm{P})$. The inorganic $\mathrm{P}$ forms $(\mathrm{Pi})$ in water or in the bicarbonate extracts are considered easily available to crops; the Pi extracted in $\mathrm{NaOH}$ solution is mainly bound to $\mathrm{Fe}$ and $\mathrm{Al}$ oxides or metal-organic complexes, and thus considered moderately labile; the $\mathrm{Pi}$ extracted in $\mathrm{HCl}$ is bound mainly to $\mathrm{Ca}$ in low-solubility precipitates, such as apatite or octacalcium phosphate, and thus considered as stable P forms [29] [30]. In the compost the total dissolved $\mathrm{P}$ in the extracts of the first three fractions was analysed after acid potassium persulpthate digestion [31] and the dissolved organic $\mathrm{P}$ ( $\mathrm{Po}$ ) was calculated as the difference between the total dissolved $\mathrm{P}$ and inorganic $\mathrm{P}$ quantified in each fraction.

Olsen P and AL-P were evaluated by the [20] and by the [21] methods. Olsen $\mathrm{P}$ was extracted by an $0.5 \mathrm{MNaHCO}_{3}$ solution buffered at $\mathrm{pH} 8.5$ at a soil to solution ratio of 1:20 and shaked during $30 \mathrm{~min}$. AL-P was extracted by a $3.5 \mathrm{M}$ ammonium lactate + acetic acid solution buffered at $\mathrm{pH} 3.75$ at a soil to solution ratio of 1:20 and shaked during $120 \mathrm{~min}$.

In all the cases, orthophosphate $\mathrm{P}$ in solution was determined by the molybdate blue method of [32].

\subsection{Statistical Analysis}

Statistical analysis of the data (Al-P and Olsen $\mathrm{P}$, sorption constants and sorption indexes were performed by one-way ANOVA with nine treatments using SPSS 26 software (http://www.spss.com). Tukey's test was used to identify differences between means at $p<\alpha=0.05$ probability level.

For nonlinear curve fitting (e.g. Freundlich and Langmuir isotherms) CurveExpert software (http://curveexpert.findmysoft.com/) was used.

\section{Results and Discussion}

\subsection{Compost Properties and $P$ forms in the Fertilisers}

The compost used in this work had a dry matter content of $610 \mathrm{~g} \cdot \mathrm{kg}^{-1}$, an organic matter content of $862 \mathrm{~g} \cdot \mathrm{kg}^{-1} \mathrm{DM}$ with a C:P ratio of 29 , and a N:P ratio of 13 (Table 1). The compost has a high organic matter content. The Dewar self-heating method [28] indicates for this compost a class of stability of IV corresponding to a finished compost. The compost had a low C:P ratio indicating 
Table 1. Selected characteristics of the compost (CP) used in the experiment.

\begin{tabular}{|c|c|c|c|c|c|c|c|c|c|c|}
\hline Properties $^{\mathrm{a}}$ & $\begin{array}{l}\text { Dry Matter } \\
\text { (DM) }\end{array}$ & $\begin{array}{c}\text { Organic } \\
\text { Matter (OM) }\end{array}$ & $\mathrm{pH}$ & $\begin{array}{c}\text { Electrical } \\
\text { Conductivity (EC) }\end{array}$ & $\mathrm{N}_{\mathrm{k}}$ & $\mathbf{P}$ & $\mathrm{K}$ & $\mathrm{Ca}$ & $C: P$ & $\mathrm{~N}: \mathrm{P}$ \\
\hline & \multicolumn{2}{|c|}{$\mathrm{g} \cdot \mathrm{kg}^{-1}$} & \multicolumn{3}{|c|}{$\mathrm{dS} \cdot \mathrm{m}^{-1}$} & \multicolumn{2}{|c|}{$\mathrm{g} \cdot \mathrm{kg}^{-1}$} & & & \\
\hline $\mathrm{CP}$ & 610 & 862 & 5.7 & 0.68 & 22.1 & 1.7 & 150 & 121 & 29 & 13 \\
\hline \multirow[t]{2}{*}{ Properties $^{1}$} & $\mathrm{Mg}$ & $\mathrm{Na}$ & $\mathrm{Fe}$ & $\mathrm{Mn}$ & $\mathrm{Zn}$ & $\mathrm{Cu}$ & $\mathrm{Pb}$ & $\mathrm{Cd}$ & $\mathrm{Ni}$ & $\mathrm{Cr}$ \\
\hline & \multicolumn{3}{|c|}{$\mathrm{g} \cdot \mathrm{kg}^{-1}$} & \multicolumn{7}{|c|}{$\mathrm{mg} \cdot \mathrm{kg}^{-1}$} \\
\hline $\mathrm{CP}$ & 9.5 & 2.6 & 2.9 & 98.2 & 490 & 105 & 12 & $<0.04$ & 14 & 22 \\
\hline
\end{tabular}

a. All data referred to dry matter excluding dry matter, $\mathrm{pH}$ and EC.

that the mineralisation of the organic carbon could be rapid after addition to soil [33], and had a slightly high N:P ratio for use as fertiliser since the adequate ratio to meet crop needs ranges between 7 - 11 [34].

The chemical properties of CP (e.g. OM, nutrients, EC, pH) and the low levels of the phytotoxic elements (e.g. $\mathrm{Cd}, \mathrm{Cr}, \mathrm{Pb}, \mathrm{Ni}, \mathrm{Cu}$ and $\mathrm{Zn}$ ), allow for its use as fertiliser of agricultural crops according to the Portuguese guidelines [35].

Concerning the $\mathrm{P}$ (Table 1 ) content $\mathrm{CP}$ had $1.7 \mathrm{~g} \cdot \mathrm{P} \cdot \mathrm{kg}^{-1} \mathrm{DM}$ with $80 \%$ of this total amount of $\mathrm{P}$ in inorganic forms (Pi). SSP had $94 \mathrm{~g} \cdot \mathrm{kg}^{-1}$ of Pi. CP had almost $50 \%$ of the total amount of $\mathrm{Pi}$ in forms easily available to crops $\left(\mathrm{H}_{2} \mathrm{O}\right.$ plus Na$\mathrm{HCO}_{3}-\mathrm{Pi}$ ) and $37 \%$ in forms considered moderate labile (NaOH-Pi), mainly bound to $\mathrm{Fe}$ and $\mathrm{Al}$ oxides or metal-organic complexes (Figure 1). Contrary to this, in SSP the forms of Pi considered easily available to crops represent almost $86 \%$ of the total amount of $\mathrm{P}$, with a trace amount of $\mathrm{NaOH}-\mathrm{Pi}$ fraction. In addition, The HCl-Pi fraction was similar between CP (15\%) and SSP (13\%).

\section{2. $\mathrm{P}$ availability after Fertilisation}

Overall the fertilisation increased significantly $(p<0.001) \mathrm{P}$ availability assessed by STP (Figure 2). We can also observe that irrespective to the STP used the variation between the treatments were similar at each sampling date (after 15 days or at 140 days of incubation). The addition of CP in combination with SSP at the higher P application rate (CP13 + SSP39) exhibited the higher STP at each sampling date, ranged between $28 \mathrm{mg} \cdot \mathrm{kg}^{-1}$ of Olsen $\mathrm{P}$ and $50 \mathrm{mg} \cdot \mathrm{kg}^{-1}$ of AL-P, S140. These levels of STP classify the soil in the high fertility class for P [36]. Irrespective to the sampling date, treatments with $\mathrm{CP}$ showed significant higher content of available $\mathrm{P}$ compared with SSP at the same rate of $\mathrm{P}$ application.

Nziguheba et al. 1998 [37] also concluded that the addition to soil of a high-quality organic material, in the case of this study the leaves of Tithonia diversifolia (Hemsley) A. Gray, applied either alone or in combination with TSP increased labile and moderately labile $P$ in the soil. The same effect on increasing $\mathrm{P}$ availability was also observed by [38] with soil amendment with farmyard manure. However, Pi forms of the fertilisers used in our work (Figure 1) could in principle justify higher amounts of available $\mathrm{P}$ (AL-P or Olsen $\mathrm{P}$ ) in SSP treatments since it had a higher amount of $\mathrm{P}$ in easily available forms to crops 


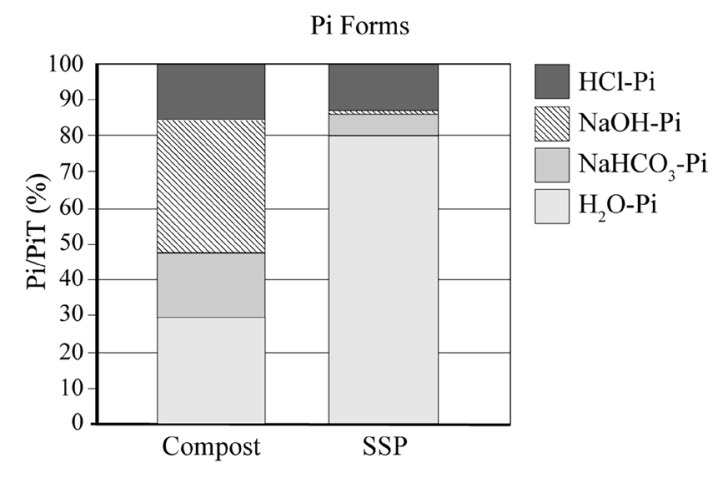

Figure 1. Pi forms $\left(\frac{\mathrm{Pi}}{\mathrm{PiT}}, \%\right)$ in the compost $(\mathrm{CP})$ and in the single superphosphate (SSP).

( $86 \%$ in $\mathrm{H}_{2} \mathrm{O}-\mathrm{Pi}$ ) than $\mathrm{CP}\left(30 \%\right.$ in $\mathrm{H}_{2} \mathrm{O}-\mathrm{Pi}$ or $50 \%$ in $\mathrm{H}_{2} \mathrm{O}$ plus $\left.\mathrm{NaHCO}_{3}-\mathrm{Pi}\right)$. So, we tried to explain the behaviour of the $\mathrm{CP}$ treatments on the increase in available P evaluating the effect of each treatment on soil P sorption at the end of the incubation time.

\subsection{Soil P Sorption at the End of the Incubation Experiment}

The adjustment of the sorption data to the Langmuir isotherm showed higher $\mathrm{R}^{2}$ values between 0.992 and 0.943 than to the Freundlich isotherm with $\mathrm{R}^{2}$ values ranged between 0.985 and 0.882 . Overall, fertilised treatments had significant lower $Q_{\max }$ and $A$ values ( $p<0.001$, Table 2). The control treatment showed the highest values of $Q_{\max }$ and $A, 145$ and $51 \mathrm{mg} \mathrm{P} \cdot \mathrm{kg}^{-1}$ respectively. The sorption data showed also that in general, CP treatments had lower $Q_{\max }$ and $A$ values compared with only SSP at the same rates of P application (e.g. CP13 + SSP39 had 89 and $24 \mathrm{mg} \cdot \mathrm{kg}^{-1}$ and SSP52 had 110 and $32 \mathrm{mg} \cdot \mathrm{kg}^{-1}$ of $Q_{\max }$ and $A$ values respectively).

The $K$ constant is related with the bonding energy of phosphate to the soil solid phase. Thus, the decrease of the affinity constant ( $K$ value) with the increase of $\mathrm{P}$ application rate suggest a reduction in the affinity of the soil solid phase for P sorption. This trend is more evident in the CP13 + SSP39 and in the SSP52 treatments with $K$ values decreasing from 0.71 in the Control treatment to 0.23 and $0.45 \mathrm{~L} \cdot \mathrm{mg}^{-1}$, respectively. The increase in soil $\mathrm{P}$ availability after addition of organic fertilisers also observed in other works [37] [38] [39] was accompanied also by a significant decrease of the P sorption capacity of the soil. The authors explained this decrease by the competition with the phosphate anion for adsorption sites by the organic anions of the organic material produced during its decomposition into the soil. In addition, in our work the sorption of the fulvic or humic acids of the compost we used may also increase the negative charge on the soil solid surface, or decrease the point of zero charge (PZC) thus making it more difficult for P sorption to occur ([9] and references herein). Indeed, the compost used in our work was a mature compost having therefore a high level of humification. Pedra et al., 2007 [40] after the addition to 


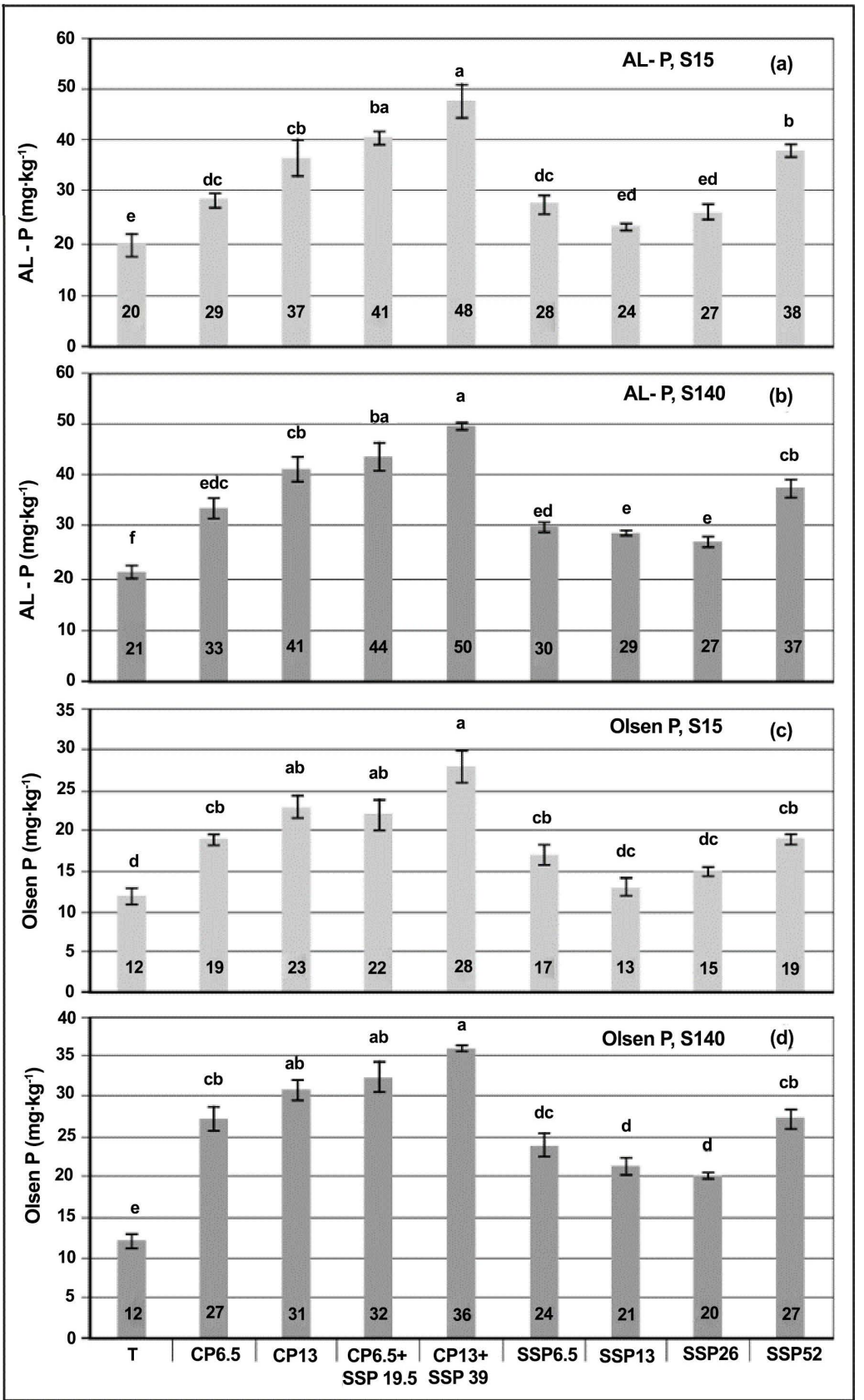

Figure 2. $\mathrm{P}$ quantified by the soil $\mathrm{P}$ tests (a) ammonium lactate method (AL-P) after 15 days (S15) of soil incubation (b) ammonium lactate method (AL-P) after 140 days (S140) of soil incubation, (c) Olsen method (Olsen-P) after 15 days (S15) of soil incubation and (d) Olsen method (Olsen-P) after 140 days (S140) of soil incubation with compost (CP) and with single superphosphate (SSP). Different letters over the bars indicate for each treatment significant differences at the $p<0.05$ level.

soil of two amendments (urban sewage sludge-USS and compost of municipal solid waste-MSWC) observed an increased in their mineralisation capacity although USS having a lower $\mathrm{C}: \mathrm{N}$ ratio showed a higher mineralisation rate than MSWC emphasizing the role of amendment maturation on the increase of the OM levels in the soil. In our work, the OM matter content of the soil after CP 
Table 2. Sorption constants obtained at the end of the incubation experiment (after 140 days of soil incubation). Different letters indicate for each treatment significant differences at the $p<0.05$ level.

\begin{tabular}{ccccc}
\hline Treatments/Sorption constants & \multicolumn{2}{c}{ Langmuir } & \multicolumn{2}{c}{ Freundlich } \\
& $Q_{\max }$ & $K$ & \multicolumn{1}{c}{$\boldsymbol{B}$} & \\
\cline { 2 - 5 } & $\mathrm{mg} \cdot \mathrm{kg}^{-1}$ & ${\mathrm{~L} \cdot \mathrm{mg}^{-1}}^{-1}$ & $\mathrm{mg} \cdot \mathrm{kg}^{-1}$ & \\
$\mathrm{~T}$ & $145 \mathrm{a}$ & $0.71 \mathrm{abc}$ & $51 \mathrm{a}$ & $0.54 \mathrm{ab}$ \\
CP6.5 & $122 \mathrm{ab}$ & $0.78 \mathrm{abc}$ & $45 \mathrm{bc}$ & $0.51 \mathrm{bc}$ \\
CP13 & $114 \mathrm{bc}$ & $0.52 \mathrm{~cd}$ & $35 \mathrm{ef}$ & $0.53 \mathrm{~b}$ \\
CP6.5SSP19.5 & $88 \mathrm{c}$ & $0.80 \mathrm{ab}$ & $37 \mathrm{def}$ & $0.41 \mathrm{c}$ \\
CP13SSP39 & $89 \mathrm{c}$ & $0.23 \mathrm{~d}$ & $24 \mathrm{~g}$ & $0.65 \mathrm{a}$ \\
SSP6.5 & $122 \mathrm{ab}$ & $0.94 \mathrm{ab}$ & $50 \mathrm{ab}$ & $0.50 \mathrm{bc}$ \\
SSP13 & $121 \mathrm{ab}$ & $0.61 \mathrm{abc}$ & $41 \mathrm{~cd}$ & $0.53 \mathrm{~b}$ \\
SSP26 & $117 \mathrm{~b}$ & $0.55 \mathrm{bcd}$ & $38 \mathrm{de}$ & $0.52 \mathrm{bc}$ \\
SSP52 & $110 \mathrm{bc}$ & $0.45 \mathrm{~cd}$ & $32 \mathrm{f}$ & $0.54 \mathrm{~b}$ \\
Significance Level & $p<0.001$ & $p<0.001$ & $p<0.001$ & $p<0.001$ \\
\hline
\end{tabular}

addition (on average $\left.46 \mathrm{~g} \cdot \mathrm{kg}^{-1}\right)$ was significantly higher $(p<0.001)$ than in SSP treatments $\left(39 \mathrm{~g}^{\mathrm{kg}} \mathrm{kg}^{-1}\right)$. So, the decrease in $\mathrm{P}$ sorption capacity observed in $\mathrm{CP}$ treatments could partially be explained by the mechanisms referred above. Nevertheless, in the works we cited above the treatments with TSP addition did not exhibit a reduction in $\mathrm{P}$ sorption capacity as we observed mainly in SSP52. In our work the high P rate used (SSP52 or CP13 + SSP39) could be higher enough to promote also a large increase in the surface coverage with phosphate anion which subsequently leads to a decrease in the bonding energy of the soil for $\mathrm{P}$ sorption of further P additions. However, CP treatments having a steeper decrease in $\mathrm{P}$ sorption capacity than the SSP treatments highlighting, in our opinion, the role of the organic matter in reducing the $\mathrm{P}$ sorption capacity of this soil.

The $b$ constant is the slope of the Freundlich isotherm plotted in the linear form and some authors like Barrow, 1974 [41] suggested that $b$ values less than 1 indicated that $\mathrm{P}$ adsorption is the main process of $\mathrm{P}$ retention to soil solid phase. The $b$ values of this work are slightly higher than 0.5 with no significant differences between the treatments indicating that the main process of $\mathrm{P}$ sorption did not changed significantly between the treatments.

A P concentration of $0.2 \mathrm{mg} \cdot \mathrm{L}^{-1}$ (standard phosphate requirement, SPR) in the soil solution is usually considered adequate for crop nutrition since it could match the critical limit for obtaining 95\% of maximum yield production [33] [37] [39] [42]. The treatment CP13 + SSP39 showed the lowest level $(p<0.001)$ of SPR (4 mg.kg-1, Figure 3(a)). In turn the control treatment showed the highest value $\left(17 \mathrm{mg} \cdot \mathrm{kg}^{-1}\right)$. Also, other works with OM addition to soil, such as poultry manure [33] or Tithonia diversifolia leaves [37] showed a reduction of SPR in soils non-calcareous, calcareous and acidic. The same trend was observed 

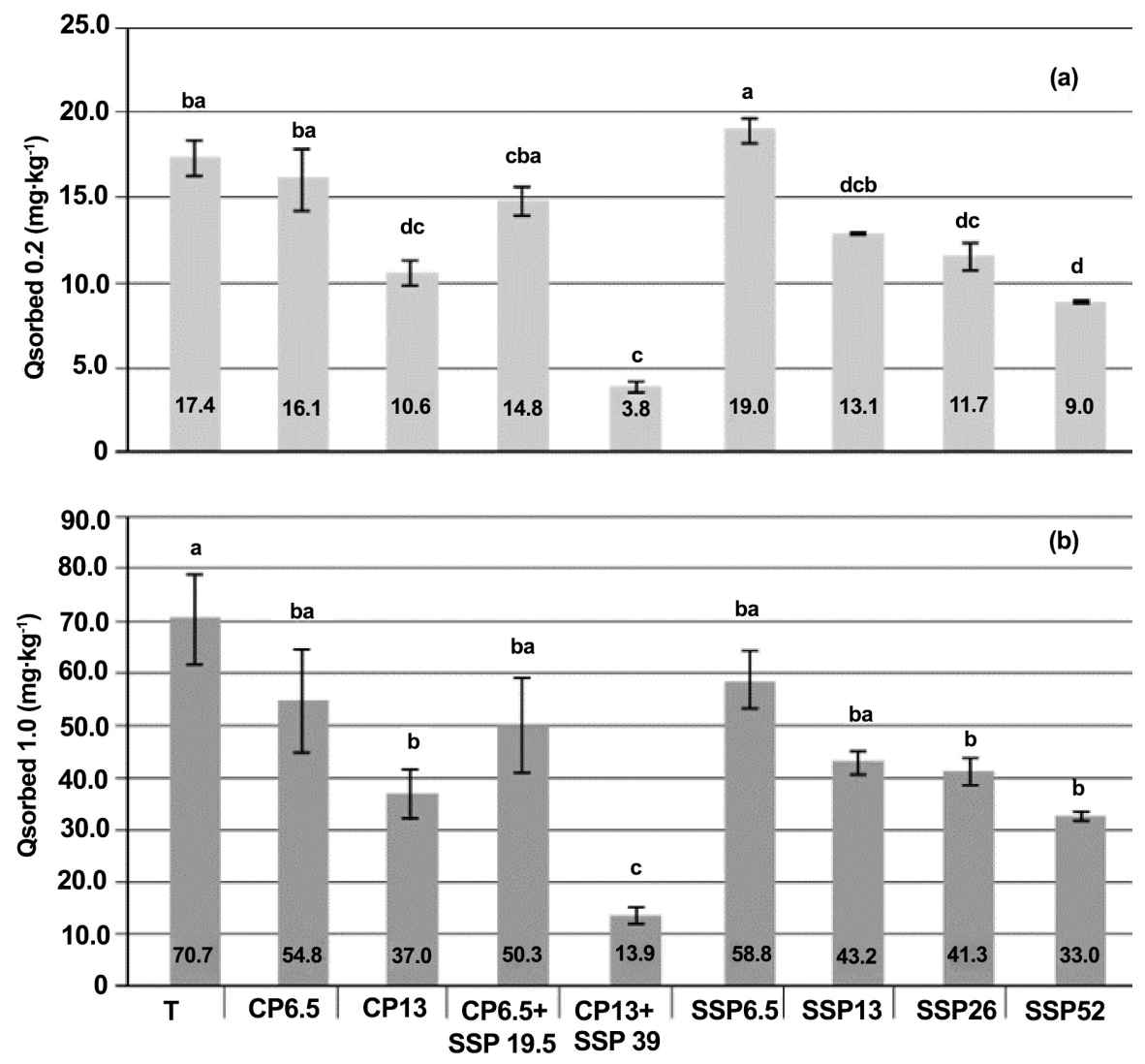

Figure 3. Amount of $\mathrm{P}$ sorbed $\left(\mathrm{mg} \cdot \mathrm{kg}^{-1}\right)$ by the soil to maintain a $\mathrm{P}$ concentration of (a) $0.2 \mathrm{mg} \cdot \mathrm{L}^{-1}$ and (b) $1.0 \mathrm{mg} \cdot \mathrm{L}^{-1}$ in the soil solution at the end of the incubation experiment (after 140 days). Different letters over the bars indicate for each treatment significant differences at the $p<0.05$ level.

between the treatments for the amount of $\mathrm{P}$ sorbed at an equilibrium $\mathrm{P}$ solution concentration of $1.0 \mathrm{mg} \cdot \mathrm{L}^{-1}$ (Qs1, Figure 3(b)). In this case the amount of $\mathrm{P}$ sorbed in the CP13 + SSP39 treatment was $14 \mathrm{mg} \cdot \mathrm{kg}^{-1}$ while in the control treatment was $71 \mathrm{mg} \cdot \mathrm{kg}^{-1}(p<0.001)$. A P concentration of $1.0 \mathrm{mg} \cdot \mathrm{L}^{-1}$ in soil solution is considered high concerning not only for crop nutrition but mainly for the risk of $\mathrm{P}$ losses from soil to water bodies, improving their risk of eutrophication from non-point sources such as soil $\mathrm{P}$ fertilisation. So, Figure 2 and Figure 3 showed that the addition of CP in combination with SSP causing a decrease in $\mathrm{P}$ sorption leads therefore to the need of the use of a lower $\mathrm{P}$ fertilisation rate to achieve not only an adequate level of soil P for crop nutrition (SPR) but also a lower risk for water bodies eutrophication (Qs1). In addition, the results of STP through the time of the incubation experiment could help to understand the maintenance of soil P levels throughout the crop cycle. Figure 2 showed an increase in the STP values with the time of incubation (from S15 to S140). This increase was significant for Olsen $\mathrm{P}(p<0.001)$ but it was not significant for AL-P $(p>0.05)$. Thus, in principle the processes that occur in the soil after fertilisation with CP and SSP should maintain adequate levels of $\mathrm{P}$ in the soil solution during the crop cycle. 


\section{Conclusions}

From the results obtained in this work, we can conclude that the organic matter content of the compost (CP) might prevent the soil $\mathrm{P}$ sorption, which further explains the higher soil $\mathrm{P}$ availability in all the CP treatments compared with the SSP treatments. This increase in the soil $\mathrm{P}$ availability after soil addition of $\mathrm{CP}$ could be explained not only by decrease of the sites of $\mathrm{P}$ sorption (decreased of $Q_{\max }$ ) but also by decrease of the bonding energy for phosphate sorption ( $K$ values decreased) to the soil solid phase.

Both STP methods used (AL and Olsen methods) were able to discriminate differences in soil $\mathrm{P}$ availability caused by the properties of the organic (compost) and of the inorganic (SSP) P fertilisers used.

The addition of CP in combination with SSP maintained high levels of soil available $\mathrm{P}$ and reduced the standard phosphate requirement. From an agronomic point of view, this behaviour draws attention to the need of reducing the amount of $\mathrm{P}$ in fertilisation.

\section{Acknowledgements}

This work was funding by the Portuguese Foundation for Science and Technology (FCT) (Project CERNAS UID/AMB/00681/2019).

\section{Conflicts of Interest}

The author declares no conflicts of interest regarding the publication of this paper.

\section{References}

[1] Frossard, E., Brossard, M., Hedley, M.J. and Metherell, A. (1995) Reactions Controlling the Cycling of $\mathrm{P}$ in Soils. In: Tiessen, H., Ed., Phosphorus in the Global Environment. Transfers, Cycles and Management, John Wiley \& Sons, New York, 107-137.

[2] Torrent, J. (1997) Interactions between Phosphate and Iron Oxide. Advances in Geoecology, 30, 321-344.

[3] Borggaard, O.K., Szilas, C., Gimsing, A.L. and Rasmussen, L.H. (2004) Estimation of Phosphate Adsorption Capacity by Means of a Pedotransfer Function. Geoderma, 11, 55-61. https://doi.org/10.1016/S0016-7061(03)00183-6

[4] Zhang, H., Schroder, J.L., Fuhrman, J.K., Basta, N.T., Storm, D.E. and Payton, M.E. (2005) Path and Multiple Regression Analyses of Phosphorus Sorption Capacity. Soil Science Society America Journal, 69, 96-106. https://doi.org/10.2136/sssaj2005.0096dup

[5] Gerke, J. and Hermann, R. (1992) Adsorption of Orthophosphate to $\mathrm{Hu}$ mic-Fe-Complexes and to Amorphous Fe-Oxide. Journal of Plant Nutrition and Soil Science, 155, 233-236. https://doi.org/10.1002/jpln.19921550313

[6] Matar, A., Torrent, J. and Ryan, J. (1992) Soil and Fertilizer Phosphorus and Crop Responses in the Dryland Mediterranean Zone. Advances in Soil Science, 18, 81-146. https://doi.org/10.1007/978-1-4612-2844-8_3

[7] Horta, M.C., and Torrent, J. (2007) Phosphorus Desorption Kinetics in Relation to 
Phosphorus Forms and Sorption Properties of Portuguese Acid Soils. Soil Science, 172, 631-638. https://doi.org/10.1097/ss.0b013e3180577270

[8] Gérard, F. (2016) Clay Minerals, Iron/Aluminum Oxides, and Their Contribution to Phosphate Sorption in Soils-A Myth Revisited. Geoderma, 262, 213-226. https://doi.org/10.1016/j.geoderma.2015.08.036

[9] Guppy, C.N., Menzies, N.W., Moody, P.W. and Blamey, F.P. (2005) Competitive Sorption Reactions between Phosphorus and Organic Matter in Soil: A Review. Australian Journal of Soil Research, 43, 189-202. https://doi.org/10.1071/SR04049

[10] Sibanda, H.M. and Young, S.D. (1986) Competitive Adsorption of Humus Acids and Phosphate on Goethite, Gibbsite and Two Tropical Soils. European Journal of Soil Science, 37, 197-204. https://doi.org/10.1111/j.1365-2389.1986.tb00020.x

[11] Kaštelan-Macan, M. and Petrovic, M. (1995) Competitive Sorption of Phosphate and Marine Humic Substances on Suspended Particulate Matter. Water Science and Technology, 32, 349-355. https://doi.org/10.2166/wst.1995.0702

[12] Antelo, J., Arce, F., Avena, M., Fiol, S., López, R. and Macías, F. (2007) Adsorption of a Soil Humic Acid at the Surface of Goethite and Its Competitive Interaction with Phosphate. Geoderma, 138, 12-19. https://doi.org/10.1016/j.geoderma.2006.10.011

[13] Fox, T.R. and Comerford, N.B. (1990) Low-Molecular Weight Organic Acids in Selected Forest Soils of the Southeastern USA. Soil Science Society America Journal, 54, 1139-1144. https://doi.org/10.2136/sssaj1990.03615995005400040037x

[14] Bolan, N.S., Naidu, R., Mahimairaja, S. and Baskaran, S. (1994) Influence of Low-Molecular-Weight Organic Acids on the Solubilization of Phosphates. Biology and Fertility of the Soils, 18, 311-319. https://doi.org/10.1007/BF00570634

[15] Haynes, R.J. and Mokolobate, M.S. (2001) Amelioeation of Al Toxicity and P Deficiency in Acid Soils by Additions of Organic Residues: A Critical Review of the Phenomenon and the Mechanisms Involved. Nutrient Cycling in Agroecosystems, 59, 47-63. https://doi.org/10.1023/A:1009823600950

[16] Maurice, P.A., Hochella, M.F., Parks, G.A., Sposito, G. and Schwertmann, U. (1995) Evolution of Hematite Surface Microtopography upon Dissolution by Simple Organic Acids. Clays and Clay Minerals, 43, 29-38. https://doi.org/10.1346/CCMN.1995.0430104

[17] Gerke, J. (2010) Humic (Organic Matter)-Al(Fe)-Phosphate Complexes: An Underestimated Phosphate Form in Soils and Source of Plant-Available-Phosphate. Soil Science, 175, 417-425. https://doi.org/10.1097/SS.0b013e3181f1b4dd

[18] Kwabiah, A.B., Stoskopf, N.C., Palm, C.A., Voroney, R.P., Rao, M.R. and Gacheru, E. (2003) Phosphorus Availability and Maize Response to Organic and Inorganic Fertilizer Inputs in a Short Term Study in Western Kenya. Agriculture, Ecosystems and Environment, 95, 49-59. https://doi.org/10.1016/S0167-8809(02)00167-6

[19] Horta, C., Roboredo, M., Carneiro, J.P., Duarte, A.C., Torrent, J. and Sharpley, A. (2017) Organic Amendments as a Source of Phosphorus: Agronomic and Environmental Impact of Different Animal Manures Applied to an Acid Soil. Archives of Agronomy and Soil Science, 63, 257-271. https://doi.org/10.1080/03650340.2017.1346372

[20] Olsen, S., Cole, C., Watanabe, F. and Dean, L. (1954) Estimation of Available Phosphorus in Soils by Extraction with Sodium Bicarbonate. United States Department of Agriculture, Washington DC.

[21] Egnér, H., Riehm, H. and Domingo, W.R. (1960) Untersuchungen uber die chemische Bodenanalyse als Grundlage für die Beurteilung des Nährstoffzustandes der Böden. II. Chemische Extraktionsmethoden zur Phosphor-und Kaliumbestimmung. 
Kunglia Lantbrukshögskolans Annaler, 26, 199-215.

[22] Horta, M.C. and Torrent, J. (2007) The Olsen P Method as an Agronomic and Environmental Test for Predicting Phosphate Release from Acid Soils. Nutrient Cycling in Agroecosystems, 77, 283-292. https://doi.org/10.1007/s10705-006-9066-2

[23] Renesson, M., Barbieux, S. and Colinet, G. (2016) Indicators of Phosphorus Status in Soils: Significance and Relevance for Crop Soils in Southern Belgium. A Review. Biotechnology Agronomy Society and Environment, 20, 257-272.

[24] IUSS Working Group WRB (2015) World Reference Base for Soil Resources 2014, Update 2015 International Soil Classification System for Naming Soils and Creating Legends for Soil Maps. World Soil Resources Reports No. 106, Rome, FAO.

[25] Despacho No. 1230/2018 (2018) Diário da República No. 25/2018.

[26] Fox, R.L. and Kamprath, E.J. (1970) Phosphate Sorption Isotherms for Evaluating the Phosphate Requirements of Soils. Soil Science Society of America Proceedings, 34, 903-906. https://doi.org/10.2136/sssaj1970.03615995003400060025x

[27] CEN EN 13346:2000 (2000) Characterization of Sludges-Determination of Trace Elements and Phosphorus-Aqua Regia Extraction Methods.

[28] Brinton Jr., W.F., Evans, E., Droffner, M.L. and Brinton, R.B. (1995) A Standardized Dewar Test for Evaluation of Compost Self-Heating. Biocycle, 36, 1-16.

[29] Traore, O., Sinaj, S., Frossard, E. and van de Kerkhove, J.M. (1999) Effect of Composting Time on Phosphate Exchangeability. Nutrient Cycling in Agroecosystems, 55, 123-131. https://doi.org/10.1023/A:1009828927161

[30] Gagnon, B., Deners, I., Ziadi, N., Chantigny, M.H., Parent, L.-E., Forge, T.A., Larney, F.J. and Buckley, K.E. (2012) Forms of Phosphorus in Composts and in Compost-Amended Soils Following Incubation. Canadian Journal of Soil Science, 92, 711-721. https://doi.org/10.4141/cjss2012-032

[31] American Public Health Association (2012) Standard Methods for the Examination of Water and Wastewater. 22nd Edition, APHA, Washington DC.

[32] Murphy, J. and Riley, J. (1962) A Modified Single Solution Method for the Determination of Phosphate in Natural Waters. Analytica Chimica Acta, 27, 31-36. https://doi.org/10.1016/S0003-2670(00)88444-5

[33] Bahl, G.S. and Toor, G.S. (2002) Influence of Poultry Manure on Phosphorus Availability and the Standard Phosphate Requirement of Crop Estimated from Quantity-Intensity Relationships in Different Soils. Bioresource Technology, 85, 317-322. https://doi.org/10.1016/S0960-8524(02)00083-4

[34] Horta, C. (2015) Sustainability of Phosphorus Fertilisation: Sources and Forms of Phosphate. Revista das Ciências Agrárias, 38, 473-483. https://doi.org/10.19084/RCA15136

[35] Decreto-Lei No. 103/115 (2015) Diário da República, No. 114.

[36] Horta, M.C., Roboredo, M., Coutinho, J. and Torrent, J. (2010) Relationship between Olsen P and Ammonium Lactate-Extractable P in Portuguese Soils. Communications in Soil Science and Plant Analysis, 41, 2358-2370. https://doi.org/10.1080/00103624.2010.508296

[37] Nziguheba, G., Palm, C.A., Buresh, R.J. and Smithson, P.C. (1998) Soil Phosphorus Fractions and Adsorption as Affected by Organic and Inorganic Sources. Plant and Soil, 198, 159-168. https://doi.org/10.1023/A:1004389704235

[38] Nest, T.V., Ruysschaert, G., Vandecasteele, B., Houot, S., Baken, S., Smolders, E., Cougnon, M., Reheul, D. and Merckx, R. (2016) The Long Term Use of Farmyard Manure and Compost: Effects on P Availability, Orthophosphate Sorption Strength 
and P Leaching. Agriculture, Ecosystems and Environment, 201, 23-33.

https://doi.org/10.1016/j.agee.2015.09.009

[39] Rashmi, I., Parama, V.R.R. and Biswas, A.K. (2016) Phosphate Sorption Parameters in Relation to Soil Properties in Some Major Agricultural Soils of India. SAARC Journal of Agriculture, 14, 1-9. https://doi.org/10.3329/sja.v14i1.29549

[40] Pedra, F., Polo, A., Ribeiro, A. and Domingues, H. (2007) Effects of Municipal Solid Waste Compost and Sewage Sludge on Mineralization of Soil Organic Matter. Soil Biology and Biochemistry, 39, 1375-1382.

https://doi.org/10.1016/j.soilbio.2006.12.014

[41] Barrow, N.J. (1974) Effect of Previous Additions of Phosphate on Phosphate Adsorption by Soils. Soil Science, 118, 82-89. https://doi.org/10.1097/00010694-197408000-00004

[42] Kamprath, E.J. and Watson, M.E. (1980) Conventional Soil and Tissue Tests for Assessing the Phosphorus Status of Soils. In: Khasawneh, F.E., Sample, E.C. and Kamprath, E.J., Eds., The Role of Phosphorus in Agriculture, America Society of Agronomy, Madison, MI, 433-469. 